\title{
The impact of generation diversity on trust within companies
}

\author{
CARMen Pires Migueles ${ }^{1}$ \\ MARCO TULIO FUNDÃO ZANINI ${ }^{1}$ \\ Juliana CARVALho ${ }^{1}$ \\ FERNANDO FILARDI ${ }^{2}$
}

${ }^{1}$ Fundação Getulio Vargas (FGV EBAPE) / Escola Brasileira de AdMINISTRAÇÃo PúbliCA e de EMPreSAS, RIO DE JANEIRO - RJ, BRAZIL

2 INSTITUTO BRASILEIRO DE MERCAdo de CAPITAIS (IBMEC), RIO DE JANEIRO - RJ, BRAZIL

\begin{abstract}
This paper investigates the causes of generational differences at work and their impact on the propensity to trust. We treated propensity to trust as a proxy for social capital, enhancing cooperation and efficiency. We assessed trust variations in a sample of five companies using combined qualitative and quantitative methods to investigate possible differences in the levels of trust among generational cohorts. We conducted 36 in depth-interviews and 24 focus groups and collected 894 valid questionnaires. The qualitative analysis suggests that differences among generations are related to the experience of time and time-flow and uncertainty and vulnerability throughout one's lifetime. The results confirm that perceived vulnerability negatively affects the predisposition to trust.
\end{abstract}

Keywords: Generations. Generational differences. Organizational trust. Cooperation.

\section{O impacto da diversidade das gerações na confiança dentro das empresas}

\section{Resumo}

Este artigo investiga as causas das diferenças geracionais no trabalho e seu impacto na propensão para confiar. Tratamos a propensão a confiar como um proxy para capital social, aumentando a cooperação e a eficiência. Avaliamos as variações de confiança em uma amostra de cinco empresas usando métodos qualitativos e quantitativos para investigar possíveis diferenças nos níveis de confiança entre grupos geracionais. Conduzimos 36 entrevistas em profundidade e 24 grupos de foco, e coletamos 894 questionários válidos. A análise qualitativa sugere que as diferenças entre as gerações estão relacionadas à experiência de tempo e fluxo de tempo, bem como à incerteza e vulnerabilidade ao longo da vida. A vulnerabilidade percebida afeta negativamente a predisposição para a confiança. Os resultados do estudo quantitativo confirmam esse achado.

Palavras-chave: Gerações. Diferenças geracionais. Confiança organizacional. Cooperação.

\section{El impacto de la diversidad de generaciones en la confianza dentro de las empresas}

\section{Resumen}

Este artículo investiga las causas de las diferencias generacionales en el trabajo y su impacto en la propensión a confiar. Tratamos la propensión a la confianza como un proxy del capital social, aumentando la cooperación y la eficiencia. Evaluamos las variaciones de confianza en una muestra de cinco empresas utilizando métodos cualitativos y cuantitativos para investigar posibles diferencias en los niveles de confianza entre grupos generacionales. Realizamos 36 entrevistas en profundidad y 24 grupos focales, y recopilamos 894 cuestionarios válidos. El análisis cualitativo sugiere que las diferencias entre generaciones están relacionadas con la experiencia del tiempo y el flujo del tiempo, así como con la incertidumbre y la vulnerabilidad a lo largo de la vida. La vulnerabilidad percibida afecta negativamente la predisposición a la confianza. Los resultados del estudio cuantitativo confirman este hallazgo.

Palabras clave: Generaciones. Diferencias generacionales. Confianza organizacional. Cooperación. 


\section{INTRODUCTION}

This paper investigates the causes of generational differences at work and their impact on propensity to trust. We approach propensity to trust as a proxy for social capital, enhancing cooperation and efficiency (Dirks \& Ferrin, 2001; Zucker, 1986). We sought to find the causes of observed conflict and communication barriers within five business organizations. Generational misalignments emerged spontaneously with more strength and frequency as the source of frustration in the efforts to promote mutual understanding and fulfill mutual expectations. In fact, previous studies have observed that generational differences demand extra efforts from leaders to reach better coordination and cooperation (Arsenault, 2004; Lyons \& Kuron, 2014). Generational differences have been abundantly researched, yet the results are inconclusive. This leaves a gap in the literature where this paper aims to examine the deeper causes of generational differences and its impact on trust and cooperation. If we intended to understand better how to improve internal cooperation, it was essential to understand generational differences within these organizations. Thus, it aims to answer the following questions: 1 ) What are the causes of differences between generations? 2) Do members of different generations differ in their propensity to trust and therefore, to cooperate?

We agree with Lyons and Kuron, (2014) who claim that each methodology provides a unique perspective on the phenomenon and it is advantageous to examine the body of evidences by treating methodologies as complementary. Thus, we choose a combination of qualitative and quantitative methods (e.g., K. P. Weeks \& Schaffert, 2019). We expected that a return to practice and to a more inductive research effort could shed new light on this subject and produce new insights. In this sense, this study assumes the social sciences perspective, who argues that each generation presents different general features acquired through experiences lived in specific historical and sociocultural contexts.

We assembled a study group of human resources professionals from those five large corporations. Their dissatisfaction with the available knowledge and its applicability to improve cooperation in teams motivated their engagement in research efforts in partnership with our research team. Hence, we divided the research into two stages: In the first stage, we sought to identify and understand the critical element for existing conflicts among generations that disturbs practical cooperation, using in-depth interviews and focal-groups with executives and employees of the studied organizations. Secondly, after identifying the issues related to generations affecting cooperation, we used a quantitative approach to measure how much generational differences might disturb cooperation, by using interpersonal trust as a proxy for firm's social capital. Social scientists (e.g., Fukuyama, 1995; Gambetta, 2000) and organizational theorists (e.g., Dirks \& Ferrin, 2001; Zucker, 1986) have emphasized the importance of trust as a proxy for social capital, enhancing cooperation and efficiency of various organizational tasks (Dirks \& Ferrin, 2001, 2002). Based on the first qualitative stage we formulated our hypotheses. Therefore, we sought to confirm the findings in the qualitative stage and understand the relationship between generational differences and trust.

\section{THEORETICAL FOUNDATIONS ON GENERATIONAL DIFFERENCES}

Different generations represent a form of diversity that poses significant challenges for cooperation across different age groups (Arsenault, 2004; Lyons \& Kuron, 2014; Standifer \&d Lester, 2020; Urick, Hollensbe, Masterson \& Lyons, 2017; K. P. Weeks, M. Weeks \& Long, 2017). Efforts have being made to adequately understand the differences among generations at the workplace, both methodological and theoretically. In fact, generational differences have been the subject of many studies, but these studies have produced somewhat inconclusive and contradictory results.

By assuming the social sciences perspective, this study is an effort to contribute to the previous research on generations in the social sciences, specifically the social forces perspective stemming from Mannheim (1952). Mannheim (1952, p. 283) argues that the events and context a generation experiences in its formative years serve as a potential basis for the emergence of a shared "inborn way of experiencing life in the world". This approach assumes inter-generational interaction as a critical for the transmission of values, skills and resources across generations. Inter-generational interaction can be either positive or negative (Arsenault, 2004, p. 125). It can be considered positive when it fosters creativity and innovation or negative when misunderstandings between generations create personal and organizational conflicts. 
Following this line of reasoning, Lyons and Kuron (2014) and Arsenault (2004) note that generational differences demand extra efforts from leaders, somehow suggesting, it negatively affects coordination. These authors point to the role of broader societal contexts as relevant for understanding the differences among generations. Works like Becton, Walker and Jones-Farmer (2014) and Cennamo and Gardner (2008) present evidence that attitudes and values do not vary significantly across generations recommending caution with grouping employees according to generation and focusing on how individual differences affects organizational behavior. However, results found by Cennamo and Gardner (2008), Twenge and Campbell (2008), Twenge, Campbell, Hoffman and Lance (2010), Smola and Sutton (2002), Van Rossem (2018), and Westerman and Yamamura (2007) showed significant differences of values across generations. These apparently contradictory results raise the hypothesis that the source of differences may not regard attitudes and values solely and that we need to deepen research on other sources for differences.

Arsenault (2004) and Lyons and Kuron (2014), following the seminal study of Mannheim (2012), note that each generation presents different general features acquired through experiences lived in a specific historical and socio-cultural context. Associating historical events to values and features of each generation, Johnson and Mislin, (2011), Li and Fung, (2012), Raines and Filipczak (1999), Yi, Ribbens, Fu and Cheng (2015), and Zemke, Lyons and Schweitzer (2017) note differences across age groups.

Other studies on different generations coexisting in the same workplace emerged from the late 1990s when longevity has increasingly appeared as a social phenomenon that affected organizations. The $20^{\text {th }}$ century, when the impact of this heterogeneity on trust becomes more explicit, the topic became the center of diverse studies, such as Becton et al. (2014), Cennamo and Gardner (2008), Johnson and Mislin (2011), Li and Fung (2012), Lyons, Schweitzer, Ng and Kuron (2012), Smola and Sutton, (2002), and Sullivan, Forret, Carraher and Mainiero (2009). In common, these authors confirmed the variation of trust according to demographic variables, such as age (Bailey \& Leon, 2019; Holm \& Nystedt, 2005; Li \& Fung, 2012; Sutter \& Kocher, 2007) and gender (Garbarino \& Slonim, 2009; Zanini, Lusk \& Wolff, 2009, Zeffane, 2018). However, understanding the relationship between these variables and the broader societal contexts remains a challenge. In this paper, we intend to contribute in this direction.

The premise behind most of the above studies is that differences may derive from values and that values change across generations. Homogeneity on values appears as the source of observable regularities in the behavior of social groups, such as a generation, and a source of conflicts and differences with other groups. This can be partially true but may not reveal other possible causes for the perception of conflict and communication difficulties. Heterogeneity and difference demand extra efforts for leaders and teams at organizations, but they are also a source of opportunity and competitive advantage (Arsenault, 2004; Gratton \& Scott, 2017), justifying the efforts to understand them better. If we question the premise that values system causes most differences, it would be justifiable to deploy a more inductive, qualitative methodology to explore other possible sources of differences on generational differences.

\section{GENERATIONAL HETEROGENEITY AND TRUST}

We follow Mayer, Davis and Schoorman (1995)'s definition of trust as the will of an individual to put oneself in a vulnerable position in a relationship with another individual or group of individuals. Their concept points towards the risk acceptance and the benefits from relationships based on trust. According to the authors, trust reduces the perception of risks derived from the interaction with co-workers; thus, helping to increase organization effectiveness as it enhances reciprocity by improving the quality of the relationships. The role of trust in cooperation and organizational coordination has been well addressed in the literature and the relationship between trust and other organizational-performance variables is the object of many studies (De Jong, Dirks \& Gillespie, 2016; Dirks \& Ferrin, 2001).

However, we lack a better understanding about the development of trust relationships related to demographic variables within business organizations, such as age and school level, that are capable of depicting the relative challenge of enhancing intergenerational cooperation (Becton et al., 2014; Cennamo \& Gardner, 2008; Lyons \& Kuron, 2014; Smola \& Sutton, 2002). Zucker (1986) notes that the larger the number of social similarities, the more the interaction agents tend to share a set 
of shared expectations, and this can imply in higher or lower trust levels. Thus, trust levels indicate the sense of belonging to a common cultural system based on expectations shared and fulfilled by the group. This argument is echoed in studies by Zak and Knack (2001), who state that heterogeneity and inequality harm trust relations. If this were true, trust levels would be lower on more heterogeneous and unequal societies and linearly higher on more homogeneous societies. This is not what empirical evidence suggests. As Zucker $(1986$, p. 63) herself notes, trust varies according to gender, age, and other individual features.

Besides, Schoorman, Mayer and Davis (2007, p. 351) also point to the need to specify the contextual variables that would lead to an understanding of the propensity to trust. In fact, research has indicated that trust should be examined at both the macro and micro levels within organizations (McEvily, Perrone \& Zaheer, 2003; Zaheer, McEvily \& Perrone, 1998), and considering specific contextual variables (Saunders, Skinner, Dietz, Gillespie \& Lewicki, 2010; Schoorman et al., 2007). As context matter, cross-national analyses are relevant to understand the causes of generational differences and its impact on trust and cooperation within organizations. However, little research has been conducted within business organizations and most of them has been carried in developed countries, particularly in North America and Europe.

On presenting their results, Holm and Nystedt (2005) note that the studies on trust show how important it is to acknowledge specific features of a society. The authors observe that Sweden ranks at the top on studies of trust, in the World Values Survey 1990-1991 (Inglehart, 1997). In the World Values Survey 2010 - 2014 study, while $60.1 \%$ of Sweden believed most people could be trusted, as did $34.8 \%$ of North-Americans but only $7.1 \%$ of Brazilians considered people trustworthy. Consequently, $92.2 \%$ of Brazilians thought one needs to be very careful with other people, $64.3 \%$ in North America and only $37.2 \%$ in Sweden.

According to the World Values Survey 2010 - 2014 on the propensity to trust across generations, Brazilian results show higher propensity to trust the younger cohort (up to 29 years old). While the works of Garbarino and Slonim (2009) and Smola and Sutton (2002) and the World Values Survey 2010 - 2014 (Inglehart et al., 2014) show the opposite in the USA, as older cohorts tend to trust more. On Sutter and Kocher's (2007) study on Austria, they assessed trust level in six different age groups and recorded that the trust-on-strangers rate increases almost linearly between elementary schoolers and adolescents; and remains almost stable in the adult population. The same tendency was found by Garbarino and Slonim (2009), that showed that trust is significantly stronger during adulthood than childhood and adolescence. Bellemare and Kröger (2003) found in the Netherlands that trust and reciprocity increase with age. According to them, age is a significant pattern. After the age of eight, trust develops until adulthood and stabilizes after that.

\section{METHODOLOGY}

We investigate generational differences and possible differences in the trust levels among generational cohorts using combined qualitative and quantitative methods with individual/group interviews and structured questionnaires. Five HR main executives of five large business organizations from different industrial sectors (telecommunication, petrochemical, beverages, logistics, and chemical) accepted to participate in the study. All five corporations have more than one thousand employees and are listed on the stock market.

The research was conducted between April and October 2017. We divided the study into two stages: 1) Initially, between April to August 2017, we conducted a qualitative research aiming to discover the core elements that could be the source of conflicts, communications difficulties and misunderstanding among individuals of different generations and how they negatively impact trust and cooperation. 2) Secondly, we used a quantitative approach to measure how much generational differences might disturb cooperation, by using interpersonal trust as a proxy for firm's social capital. Thus, we distributed and collected questionnaires between August and October 2017. 


\section{Qualitative stage procedures and analysis}

On the qualitative stage, using an inductive approach, we sought to have a fresh look into data that could bring new elements to the analysis. We used a combination of two methods: in-depth interviews and focal-groups. A trained anthropologist from our team and a research assistant carried all interviews. A criterion of generational homogeneity was used to assemble the groups. The collected data were treated through content analysis. We recorded members' speeches, categorized the topics, manually counted the frequency of appearance of topics marking texts with a color code, and filled data gaps with data collected through new rounds of interviews. With the focal groups, we were interested in the logic of the argument people used to describe difficulties in interacting with members of other generations and the opinion, especially counter-argument, of their cohort. We looked for response-behavior patterns in each generational group.

In each of the study organizations, individuals were selected randomly, according to their accessibility and generational cohort. As the volunteers showed up for the study, we conducted 36 individual in depth-interviews. As a pattern started to emerge, we assemble the following volunteers into 24 focus-groups to promote a debate on the challenges of each generation cohort. Individual interviews and focus-groups had a duration of 1 hour and 30 minutes each adding to a total of 90 hours of interviews.

We collected stories and the arguments on actual events of frustration when exchanging with other generation and their opinion on its causes. At first, we proceeded with discourse analysis as proposed by Geertz (1977), as an interpretative effort to understand the web of meaning that is the key to proper discourse decoding. Later, we opted for stories and narratives about concrete experiences and frustrating expectancies on real interaction in order to collect evidence for the analysis of a "habitus" as proposed by Bourdieu (1977). It was more suitable to interpret the ellipses and gaps observed in the discourse of familiarity, when the interviewee fail to put into words, analytically, what they intend to express. Resorting to real stories and at length, narratives on concrete problems were useful to fill these gaps.

We chose to step away from the study of values, attitudes and specific preferences to carefully explore the synthesis that Lyons and Kuron (2014) produced in their analysis of different authors, based on Mannheim (2012). The authors affirm that the social context matters and is relevant when observing generational differences, understanding a generation as a group of individuals born within the same historical and socio-cultural context. However, the relevance of observing generational differences is proportional to the capacity of to avoid long descriptive lists of singularities and specificities and to find the thread that connects historical and socio-cultural elements to the chain of exchange and reciprocity in a concrete social context, thus affecting cooperation. We needed to find a trail to discover what, in the socio-cultural and historical contexts, could hurt the chain of reciprocity, thus disturbing cooperation.

We increased the length of the interviews to allow them to describe the concrete situations that produced discomfort. We expected to understand the formative experiences that gave origin to a given "habitus" that shed new light on the subject. Lyons and Kuron (2014) mention the possible relevance of the concept of "habitus" in generational differences, defined as a mode of thought and action. Although there was no explicit reference to the work of Bourdieu (1977), it raised for us the possibility of proceeding as Bourdieu suggested and looking at the core of those differences more as a state of the body than as a state of mind. In this case, values and all the explanations for attitudes and behaviors should be treated not as concrete evidence of the interviewees value system, but as an effort to explain something that exists first as a concrete experience, a body automatism, a habitus, from which the discourse is a poor, secondary effort to objectify (Bourdieu, 1977, p. 21). It was our job to find explanations. 


\section{RESULTS}

\section{The emerging qualitative data analysis and its theoretical implications}

The content analysis led us to conclude that the source of conflict among the generations had three leading causes: 1) The variation on the relation of individuals to time, to the authentic experience of the speed of the flow of events. This is a crucial element to understand the conflict, and the unfulfilled expectative on different generations encounter, as we expected to be able to demonstrate below. 2) The relation between the domain of experience and its projection on the domain of expectative, which produced significant frustration and a sense of disorientation. 3) The experience of uncertainty and the risks associated with opportunities throughout one's lifetime. We selected a few extracts from the interviews to present evidence of this.

A member of veterans (the generation born during World War II) says:

"When I started in this company, and I am here for almost 45 years, we did what was necessary to be done. The boss would ask you to do something. You would go on and do it. And you were learning as you did as you were told ... In time, we accumulated knowledge, experience, and the necessary relationships to support us in our career. There was value in your boss' experience and could learn from him.... We had a feeling we were getting the right clues and the right relationships. Of course, there were moments of terrible boredom. It was part of it... Now those youngsters are always in a huge hurry.... They are not interested in the experience. They can't sit still and listen. If you ask them to show you how they discovered something on their phones, they will show you so fast you can't follow....then they look at you as if you were stupid...".

Alternatively, the speech of a baby-boomer, that expresses a perception that was also common at this generation:

"The young generation enters the company ready to leave. They came after the experience, success, recognition, opportunity to learn, and a job that allows them to balance work and private life, learning, and leisure. They want everything at once. We need to look at the clients, at the processes, at the financial flow. A company is a complex system. It takes time to learn. I try to challenge my trainees. However, there is also much work for me to do, as well. If I get distracted, I lose one of them. They change areas or even change company... When I think I found a talent to develop, he or she leave my team in search of new opportunities or experiences. They seem so unable to cope with the necessary time for things to happen".

The speech of a $Y$ generation:

"I can't understand how people stay in one job so long... For me, it seems like a life wasted. It seems a type of accommodation.... a fear of taking their own life and career in their own hands. I like working here. However, I have a deadline for myself. If I don't reach a top position in 3 years, I will find opportunities elsewhere".

Alternatively, in the speech of an $\mathrm{X}$ generation:

"People ask me to wait, promise me a career. I don't know if I want a career or a career here. I make an effort. However, it is really boring. If my boss were transparent about the goals and objectives, I am sure I could help to find innovative solutions. However, they want us to use "tested processes and solutions." No! It is rather stupid to do that. They don't listen. I am not staying here waiting until they give me the right opportunity. I have friends who are earning more than me".

Naturally, an in-depth explanation of each of these interviews would lead us to complex historical, sociological, and technological contexts that framed individuals' experience. However, to understand the impact of the difference in social exchange, we need to unveil the deeper structure that constitutes the core of their differences and its impact on social exchanges. 
Proceeding with this search, we could observe that this different physical experience of the speed of time created a massive demand for individuals in face-to-face interactions. It is a clash on different sets of tacit knowledge acquired throughout each generation's lifetime. Communicating and collaborating with people that has the same age demands less effort because the tacit knowledge synchronizes time experiences and forms of dealing with the course of interaction. The older the individual, the more comfortable they are with long, linear, and logically articulated narrative. The younger the individual, the more used they are to multiple stimuli, simultaneous activities, and multiple logical possibilities. At first, the experience of speed and time could almost be reduced to the individuals' experience with technology, producing a sort of technological determinism as causal to generational differences. However, this would be an inadequate reduction of what our data was indicating.

The veterans and the baby-boomers always mentioned the lack of opportunities, the poverty of Brazil until the early 1970s, and the dependence on a few good employers to have stability. Uncertainty and risk mingled in their personal history, where patience, perseverance, and the capacity to build the right relationships were critical. The first group of generation $\mathrm{X}$, on the other hand, entered the labor market after the economic growth of the 1970s but faced a deep depression and high inflation of the 1980s. They experienced the new democratic opening after 21 years of the military government. New civil liberties and economic difficulties framed the historical context of their youth. The younger members of Generation $Y$ grew up at a time in which both civil rights and liberties could be taken for granted. They benefit from economic stability, unlimited access to information, and the growth of Brazilian new middle class, with significant impact on the growth of consumer marketing, job opportunities, and the growth of entrepreneurial mindset. More opportunities, information, and education seem to have contributed to raising a more self-confident and independent generation. Flexibility, autonomy, and proactivity were perceived as essential to success.

Some studies have shown that most firms have at least three different generations coexisting in the same workplace: baby boomers (born from the end of the Second World War until the mid-1960s), the X Generations (born between the mid-1960s until the late 1970s) and the Y Generation (born between the early 1980s and the early 2000s). There is no consensus on the overall literature about the exact years for the age groups composing each of the generations (Becton et al., 2014; Lyons \& Kuron, 2014; Smola \& Sutton, 2002; Twenge et al., 2010).

Mannheim (2012) influences most studies on the subject and points to the inadequacy of imposing the generational configuration of one society into another, adding that a society's unique context should be considered before a generational scheme is adopted in the research. Accordingly, besides the relevant historical episodes presented above to propose the above classification (that somehow affected the entire Western Hemisphere), our qualitative study confirms the relevance of local historical and economic context for framing individuals' experiences. In this sense, values on the discourse analysis emerged as a type of "behavioral resource" to assure adaptability to external circumstances. This gives us a clue to the causes of variation of research results across socioeconomic and historical contexts. There is an element of "you must be $X$ to reach $Y$ result" that is the validity test behind the defense of a value system. Rather than constituting a priori preference of individuals, values appear as a skill or an ability one needs to practice to successfully adjust to a given external situation.

Weber $(1978$, p. 18) noted that the more rigorous the rationality related to the expected results, as the ends of a given course of action, the more similitude is observable in behavior within a group or society. Homogeneities, regularities, and continuities on attitudes and actions derived from rational efforts to adjust one's behavior towards desired ends on a given context are, many times, more stable than those regularities that emerge from rules and values. Therefore, the socio-cultural and historical experience emerges as the hard ground to which a set of values emerges as preferable to another.

The different efforts that each generation has to make to adjust to external situations somehow explains the difference in their tacit knowledge and corresponding values, therefore the elements of heterogeneity among them. However, we are still lacking a powerful theoretical synthesis that would allow us to grasp the impact on their perception of raising conflict and communication barriers, because, as in the discourse of a veteran presented above, differences could produce complementarity, as he saw in his relation to his superiors 50 years ago. 
Our observations led us to conclude that heterogeneity of life experiences significantly affects the expectations regarding others' behaviors in social interactions. Increased longevity and technological transformation contributed to creating more significant gaps in experience among different age groups. This reduces the common grounds based on which reasonable foreseeability and expectation regarding others' behavior could hold. All rational calculations can only claim to be so if they process reasonable estimates of possible effects and consequences of one's actions. The role of expectations in social life is extremely relevant for trust and cooperation (Gambetta, 2000; Zucker, 1986).

These differences are especially significant in the older generations, for at the end of a 40-year career, the skills and knowledge built at the beginning are substantially eroded (Gratton \& Scott, 2017). That would place the more senior employees in a more vulnerable position. The decline of cognitive abilities can be compensated by the growth of non-cognitive abilities with age and experience, which allows the undertaking of more complex tasks (Hennekam, 2016), but these need to be valued by others. The perception of the vulnerability of veterans and baby-boomers can be related to how their abilities are valued in a given organizational context. Our findings are supported by Zucker's (1986) discussions on heterogeneity as a source of disruption of trust. The author argues that, contrary to heterogeneity, that disrupts basic background expectations, social similarities generate common expectations that increase integration and serve as an indicator of trust.

From our data, we could observe that expectation is, at the same time, a probability and a wish. It is a subjective state derived from an orientation towards the future, in which the individual projects past experiences and believes it shall repeat. It somehow mingles foreseeability and premeditation, where accurate and reliable foreseeability is critical for successful premeditation. Rational individuals tend to adjust their behavior to this projection as the most reliable guess. The perception of reciprocity and cooperation occurs when the other individual, in social interaction, corresponds to this expectation, promoting more frank exchanges. Continuous experiences of frustrated expectations reduce both faith and hope that interaction should be productive. Random behavior is analogous to refusing to cooperate. In this sense, heterogeneity can be a source of significant disorientation, as it increases the possibilities of unforeseeable courses of action, reducing the possibility of construction of reasonable estimates as a basis for social action.

Atkinson (2007) notes that increased demand on extra-role behavior can affect trust and the psychological contract in organizations, negatively affecting organizational trust. The described differences raise the hypothesis that generation conflicts affect the need for extra-role behaviors and efforts, and can negatively impact organizational trust in a more generalized form. This, somehow confirms Atkinson's (2007) perception that the lack of clarity regarding obligations in relational contracts (which are open-ended by nature), less specific and built on the course of social exchanges, may be perceived as a breach of the psychological contract, leading to a perception of lack of "mutuality".

We concluded, from the qualitative stage of our research, that each generation had different levels of propensity to trust according to their exposition to risk and vulnerability. Those who experienced more uncertainty and hardship throughout life would be less likely to trust. So that older people, with life experience in more difficult political and economic contexts, would be negatively affected in three ways: first because of their experiences of hardship; second because of the erosion of their skills and knowledge and third because most organization's retention efforts are directed towards young talents. As their lifelong experience would be insufficient to cope with the new situations, and they had fewer resources to adjust, they would be less likely to cooperate. Without recognition of the value of their contribution, which would demand another relation to time, speed, and experience from the younger generations, their disposition to engage in exchange and reciprocity should decline. 


\section{Complementary quantitative analyses}

We discovered differences among the generations and sought to verify, at the quantitative stage, whether those differences produced variation in the propensity to trust across generations. Previous studies investigating the relationship between trust and age have frequently shown that trust increases positivley throughout age (Bailey \& Leon, 2019; Li \& Fung, 2012; Paulin \& Haase, 2015). However, as previously pointed in this paper and highlighted by Li and Fung (2012), most research on trust across generations was made in developed individualistic countries, such as the USA and Europe. Therefore, it is key to understand how the context can play an important factor that affects trust levels thought time.

For instance, Li and Fung (2012) have found significant differences in trust across individualistic and collectivistic cultures and between countries in different development levels. In a study about interpersonal trust in the US, Clark and Eisenstein (2013) have shown that civil detachment has affected trust. In a way, interpersonal trust is weaker in younger cohorts. Studies like the ones by Clark and Eisenstein (2013) and Li and Fung (2012) show how contextual factors have a key role in determining how trust is fostered across one's lifespan. Thus, in the present study, after clarifying the issues related to how generational issues affect trust, a quantitative approach was deployed to measure the extent to which generational differences might disturb cooperation by using interpersonal trust as a proxy for a firm's social capital. A complementary survey in the five studied companies was used to verify the impact of the findings on the propensity to trust. Questionnaires were distributed and collected between August and October 2017. We obtained 894 valid questionnaires out of 1200 distributed (a 74.5\% response rate). Based on our previous qualitative analysis on generational groups and assuming that vulnerability negatively affects trust (and therefore the older Baby Boomer generation, who are in a more vulnerable position, will tend to trust less than the younger $X$ and $Y$ generations), we formulate the first groups of hypotheses:

\section{H1a: Members of Generation Y tend to trust more than Baby Boomers.}

H1b: Members of Generation X tend to trust more than Baby Boomers.

H1c: Members of Generation Y tend to trust more than members of Generation X.

For our quantitative analyses, we defined the age groups as follows: Baby Boomers - born between 1945 and 1964, Generation X - born between 1964 and 1980, and Generation Y - born between 1981 and 1997. We collected questionnaires in five organizations between August and October 2017. We obtained 894 valid questionnaires from 1200 distributed questionnaires (a 74.5\% response rate). Members of the traditionalist generation (born during World War II) are still active in one of the studied corporations, and members of Generation Z (born after 2000) have roles as interns. We interviewed them but chose not to include these data in the quantitative analysis due to the small sample size ( 8 traditionalist individuals and 17 Generation $Z$ individuals).

Regarding the studied variables, interpersonal trust was measured using the latent constructs extracted from the Behavioral Trust Inventory (Gillespie, 2003), specifically, the version translated into Portuguese that was tested and used by Zanini (2007). It divides trust into three dimensions: Trust in the Supervisor, Trust in the Peer and Trust in the Team. Each variable is composed of 10 items measured on a 7-point Likert-type scale. We averaged the responses regarding the three dimensions to form a global perception of trust. When taken together, the scale items showed high reliability $(\alpha=0.95)$. Generations were delineated using dummy variables that divided our sample into three subgroups: Baby Boomers (32.2\% of the sample), Generation X (38\%), and Generation Y (29.8\%). As controls, we considered educational level, sex, hierarchical level, time in the company and work department, all of which will be addressed in a future paper.

To test the impact of the different generations on trust, we conducted a multiple regression analysis. The results showed a significant difference between Baby Boomers and Generation $Y(b=0.20 ; p<0.001)$ and between Baby Boomers and Generation $X(b=0.13 ; p<0.05)$, indicating that trust levels are higher among members of Generations $X$ and $Y$. Thus, Hypotheses $1 a$ and $1 b$ are supported. However, there are no significant differences between Generations $Y$ and Generation $X(b=-0.07 ; p=n o n$. sig), which leads to the rejection of Hypothesis 1c. Table 1 presents our results. 
Table 1

Multiple linear regression models of trust

\begin{tabular}{|c|c|c|c|}
\hline \multicolumn{4}{|c|}{ DV: Trust } \\
\hline & Model 1 & Model 2 & Model 3 \\
\hline X Generation & & $\begin{array}{c}0.129 * \\
(0.0641)\end{array}$ & $\begin{array}{l}-0.0658 \\
(0.0616)\end{array}$ \\
\hline Y Generation & & $\begin{array}{c}0.195 * * * \\
(0.0745)\end{array}$ & \\
\hline Baby Boomers & & & $\begin{array}{c}-0.195 * * * \\
(0.0745)\end{array}$ \\
\hline \multicolumn{4}{|l|}{ Controls } \\
\hline Education Level & $\begin{array}{c}-0.131 * * * \\
(0.0318)\end{array}$ & $\begin{array}{c}-0.137 * * * \\
(0.0324)\end{array}$ & $\begin{array}{c}-0.137^{* * * *} \\
(0.0324)\end{array}$ \\
\hline Time in the Company & $\begin{array}{c}0.0535 * * * \\
(0.0145)\end{array}$ & $\begin{array}{l}0.0303^{*} \\
(0.0169)\end{array}$ & $\begin{array}{l}0.0303^{*} \\
(0.0169)\end{array}$ \\
\hline Management Position & $\begin{array}{c}0.0682 * * * \\
(0.0263)\end{array}$ & $\begin{array}{l}0.0559 * \\
(0.0267)\end{array}$ & $\begin{array}{l}0.0559 * \\
(0.0267)\end{array}$ \\
\hline Marketing and Sales & $\begin{array}{l}0.320+ \\
(0.174)\end{array}$ & $\begin{array}{l}0.331+ \\
(0.174)\end{array}$ & $\begin{array}{l}0.331^{\dagger} \\
(0.174)\end{array}$ \\
\hline Finance & $\begin{array}{l}0.0358 \\
(0.182)\end{array}$ & $\begin{array}{l}0.0235 \\
(0.182)\end{array}$ & $\begin{array}{l}0.0235 \\
(0.182) \\
\end{array}$ \\
\hline Administrative Management & $\begin{array}{c}0.233 \\
(0.181)\end{array}$ & $\begin{array}{c}0.221 \\
(0.181)\end{array}$ & $\begin{array}{c}0.221 \\
(0.181) \\
\end{array}$ \\
\hline Human Resources & $\begin{array}{l}0.415 * \\
(0.191)\end{array}$ & $\begin{array}{l}0.396 * \\
(0.191)\end{array}$ & $\begin{array}{l}0.396 * \\
(0.191)\end{array}$ \\
\hline Engineering & $\begin{array}{l}0.357^{*} \\
(0.174)\end{array}$ & $\begin{array}{l}0.362 * \\
(0.174)\end{array}$ & $\begin{array}{l}0.362^{*} \\
(0.174)\end{array}$ \\
\hline Support Systems & $\begin{array}{l}0.436 * \\
(0.182)\end{array}$ & $\begin{array}{l}0.429 * \\
(0.182)\end{array}$ & $\begin{array}{l}0.429 * \\
(0.182)\end{array}$ \\
\hline Constant & $\begin{array}{c}4.816^{* * * *} \\
(0.191)\end{array}$ & $\begin{array}{c}4.840 * * * \\
(0.191)\end{array}$ & $\begin{array}{c}5.035 * * * \\
(0.209)\end{array}$ \\
\hline Observations & 1,552 & 1,552 & 1,552 \\
\hline R-squared & 0.050 & 0.054 & 0.054 \\
\hline
\end{tabular}

Standard errors in parentheses

*** $p<0.001, * * p<0.01, * p<0.05,+p<0.10$

Source: Elaborated by the authors

\section{DISCUSSION}

The qualitative stage confirmed that different socio-historical life experiences increase heterogeneity across generations, impacting each generation's propensity to trust and creating a negative impact on social exchanges. However, returning to the data, we note that this finding is the tip of the iceberg of broader socioeconomic and cultural transformations. The propensity for trust to change across generations seems to be caused by different degrees of exposition to risk and vulnerability. In this sense, we observed that the older generations tend to trust less than the younger. Our hypothesis, to explain this result and to be verified in future studies is that the erosion of capabilities may be more relevant to perceived vulnerability and that it was larger for the Baby-Boomers and smaller for generations $X$ and $Y$. It may reduce the latter perception of vulnerability and increase their response capacity to changes. The issue of retaining or losing capabilities needs to be better understood. 
Using quantitative methods, we compared differences in propensity to trust between members of Generations $X, Y$, and Baby Boomers. Our results showed a significant difference in trust levels between members of generations $X$ and $Y$ when compared to Baby Boomers, but no significant differences between generations $X$ and $Y$. This outcome evidenced that generations $X$ and $Y$ are similar in levels of trust, but they present higher levels of trust when compared to Baby Boomers.

Additionally, our study contributes to demonstrate that context matter. Results in our study in Brazil were not identical to Holm and Nystedt (2005) in Sweden but shows a similar tendency. They reported higher trust levels in younger generations, different from other studies, like Bellemare and Kröger (2003) in the Netherlands, who found that trust and reciprocity increase with age, and Sutter and Kocher (2007) in Austria, who concluded that trust increases in a linear progression to aging.

Sweden's results change on the newer edition of the World Value Survey (2010-2014), revealing a trend change, inverting the previous tendency. On recent studies, older cohorts tend to trust more. The comparison among these studies compromised by methodological differences, but these changes in results tend to confirm the relevance of specific historical context in their influence on trust behavior. It is important to note that the original research deployed by Holm and Nystedt (2005) is from the late 1990s. The younger cohort then should now be at their late 40's and early 50's. We can conclude that the same individuals are now on an older generation and yet retain higher propensity to trust. A promising hypothesis to investigate is whether less exposition to uncertainty and vulnerability during early ages affects the propensity to trust throughout a lifetime.

Our results corroborate with the World Value Survey data that shows a general tendency that the older generations trust less than, the younger generations in Brazil. Based on the World Value Survey 2010-2014, youngsters (up to 29 years) in Brazil trust more than individuals in the age group 30-49 years or older. According to our results, the more experienced and educated the individuals, the less likely to trust. The younger and less educated are more likely to trust and therefore engage in social exchanges. If Sweden's trend repeats in Brazil, in twenty years or more, the older generation will tend to trust more. The impact of these changes in economics still needs to be better understood, but one thing is sure: the study of the propensity to trust across generations reveals a dynamic element hidden under the surface of observable behaviors with consequences for cooperation and therefore for organizational performance.

\section{CONCLUSIONS}

This study shows that differences in values among generation cohorts are the result of a more profound transformation of lived experiences that increases heterogeneity among different age groups. This is significant because this theme has been abundantly researched, yet the results are inconclusive.

By using an inductive approach, we conclude that different socio-cultural, historical and technological experiences produce a different tacit relation to time and time-speed and a relative erosion of knowledge and experience of the older groups. This is a relevant source of heterogeneity among generations. The experience of economic affluence, political stability, and access to information tend to increase the propensity to trust. The older generations, facing rapid changes, experience a double frustration: with the speed with which younger people cope with change and with the partial inadequacy of their tacit knowledge to cope with it. They are the group with less propensity to trust and, therefore, with less propensity to cooperate in knowledge exchanges.

The comparison of our results from the quantitative stage to other previous researches points to the conclusion that the propensity to trust changes according to generation, but not in the same direction in all societies. Broader social and economic context strongly influences this tendency. It would be interesting to verify, in future research, if this variation derives from moments of growth of uncertainty and vulnerability in different societies. 
Our results suggest heterogeneity among generations tends to have consequences both to knowledge transfers and to human resources management of an aging labor force. Independently of the direction of change in the propensity to trust across generations, growing longevity may negatively affect the propensity to trust in a generalizable manner, negatively affecting coordination and cooperation and, consequently, economic performance. We concluded that, in Brazil, the more experienced individuals have lower propensity to trust and therefore, to cooperate. Given that they hold relevant knowledge for organizations devising strategies and methodologies to support them in engaging in knowledge exchanges might be relevant for the success of succession processes and knowledge management processes.

Our study has practical as well as academic implications. The present study provides relevant contributions for management practices regarding generational gaps in the workplace, by confirming the differences in the levels of trust among generational cohorts. It also provides important explanation about the causes of such differences. Besides, most research has been carried in developed countries, particularly in North America and Europe. Research in an emerging economy, like Brazil, with its contextual specificities therefore, introduces new scientific insights. The differences between Brazilian historical processes and those found in European and American societies may not only affect the experience (and thus the level of trust) between generational groups, but also the historical milestones that determine the beginning and end of each generation. Further research should deeper the sources of such differences among generations and explore the local specificities that affect the determination of generational cohorts. Despite of the importance of these findings, we have not tested this effect in a larger sample, which we consider a limitation. 


\section{REFERENCES}

Arsenault, P. M. (2004). Validating generational differences: A legitimate diversity and leadership issue. Leadership \& Organization Development Journal, 25(2), 124-141.

Atkinson, C. (2007). Trust and the psychological contract. Employee Relations, 29(3), 227-246.

Bailey P. E., \& Leon T. (2019). A systematic review and meta-analysis of age-related differences in trust. Psychology and Aging, 34(5), 674-685.

Becton, J. B., Walker, H. J., \& Jones-Farmer, A. (2014). Generational differences in workplace behavior. Journal of Applied Social Psychology, 44(3), 175-189.

Bellemare, C., \& Kroger, S. (2003). On Representative Trust (Discussion Paper, No 2003-47). Tilburg, the Netherlands: Tilburg University, Center for Economic Research.

Bourdieu, P., \& Nice, R. (1977). Outline of a Theory of Practice (Vol. 16). Cambridge, UK: Cambridge University Press.

Cennamo, L., \& Gardner, D. (2008). Generational differences in work values, outcomes and person-organisation values fit. Journal of managerial psychology, 23(8), 891-906.

Clark, A. K., \& Eisenstein, M. A. (2013). Interpersonal trust: An age-period-cohort analysis revisited. Social science research, 42(2), 361-375.

De Jong, B. A., Dirks, K. T., \& Gillespie, N. (2016). Trust and team performance: A meta-analysis of main effects, moderators, and covariates. Journal of Applied Psychology, 101(8), 1134-1150.

Dirks, K. T., \& Ferrin, D. L. (2001). The role of trust in organizational settings. Organization science, 12(4), 450-467.

Dirks, K. T., \& Ferrin, D. L. (2002). Trust in leadership: Meta-analytic findings and implications for research and practice. Journal of applied psychology, 87(4), 611-628.

Fukuyama, F. (1995). Trust - The Social Virtues and the Creation of Prosperity. Harmondsworth, Middlesex: Penguin Books.

Garbarino, E., \& Slonim, R. (2009). The robustness of trust and reciprocity across a heterogeneous US population. Journal of Economic Behavior \& Organization, 69(3), 226-240.

Gambetta, D. (2000). Can we trust. Trust: Making and breaking cooperative relations, 13, 213-237.

Geertz, C. (1977). The interpretation of cultures. New York, NY: Basic Books.

Gillespie, N. (2003, August). Measuring trust in working relationships: the behavioral trust inventory. In Proceedings of the Academy of Management Conference, Seattle, WA.

Gratton, L., \& Scott, A. (2017). The corporate implications of longer lives. MIT Sloan Management Review, 58(3), 63-70.

Hennekam, S. (2016). Employability and performance: a comparison of baby boomers and veterans in The Netherlands. Employee Relations, 38(6), 927-945.
Holm, H., \& Nystedt, P. (2005). Intra-generational trust-a semiexperimental study of trust among different generations. Journal of Economic Behavior \& Organization, 58(3), 403-419.

Inglehart, R. C. (1997). Modernization and Postmodernization, Cultural, Economic, and Political Change in 43 Societies. Princeton, NJ: Princeton University Press.

Inglehart, R. C., Haerpfer, A., Moreno, C., Welzel, K., Kizilova, J., Diez-Medrano, M., ... Puranen, B. (2014). World Values Survey: Round Six - Country-Pooled Datafile Version. Madrid, España: JD Systems Institute. Retrieved from http://www.worldvaluessurvey. org/WVSDocumentationWV6.jsp

Johnson, N. D., \& Mislin, A. A. (2011). Trust games: A meta-analysis. Journal of Economic Psychology, 32(5), 865-889.

Li, T., \& Fung, H. H. (2012). Age differences in trust: An investigation across 38 countries. Journals of Gerontology Series B: Psychological Sciences and Social Sciences, 68(3), 347-355.

Lyons, S. T., \& Kuron, L. (2014). Generational differences in the workplace: A review of the evidence and directions for future research. Journal of Organizational Behavior, 35(S1), S139-S157.

Lyons, S. T., \& Schweitzer, L. (2017). A Qualitative Exploration of Generational Identity: Making Sense of Young and Old in the Context of Today's Workplace. Work, Aging and Retirement, 3(2), 209-224.

Lyons, S. T., Schweitzer, L., Ng, E. S., \& Kuron, L. K. (2012). Comparing apples to apples: A qualitative investigation of career mobility patterns across four generations. Career Development International, 17(4), 333-357.

Mannheim, K. (2012). Essays on the Sociology of Culture. London, UK: Routledge.

Mayer, R. C., Davis, J. H., \& Schoorman, F. D. (1995). An integrative model of organizational trust. Academy of management review, 20(3), 709-734.

McEvily, B., Perrone, V., \& Zaheer, A. (2003). Trust as an organizing principle. Organization Science, 14(1), 1-106.

Poulin, M. J., \& Haase, C. M. (2015). Growing to trust: Evidence that trust increases and sustains well-being across the life span. Social Psychological and Personality Science, 6(6), 614-621.

Saunders, M. N. K., Skinner, D., Gillespie, N., Dietz, G., \& Lewicki, R. (2010). Organizational trust: A cultural perspective. Cambridge, UK: Cambridge University Press.

Schoorman, Mayer, R. C., \& Davis, J. H. (2007). An Integrative Model of Organizational Trust: Past, Present, and Future. The Academy of Management Review, 32(2), 344-354.

Smola, K., \& Sutton, C. D. (2002). Generational differences: Revisiting generational work values for the new millennium. Journal of Organizational Behavior: The International Journal of Industrial, Occupational and Organizational Psychology and Behavior, 23(4), 363-382. 
Standifer, R. L., \& Lester, S. W. (2020). Actual Versus Perceived Generational Differences in the Preferred Working Context: An Empirical Study. Journal of Intergenerational Relationships, 18(1), 48-70.

Sullivan, S. E., Forret, M. L., Carraher, S. M., \& Mainiero, L. A. (2009). Using the kaleidoscope career model to examine generational differences in work attitudes. Career Development International, 14(3), 284-302.

Sutter, M., \& Kocher, M. G. (2007). Trust and trustworthiness across different age groups. Games and Economic behavior, 59(2), 364-382.

Twenge, J. M., \& Campbell, S. M. (2008). Generational differences in psychological traits and their impact on the workplace. Journal of managerial psychology, 23(8), 862-877.

Twenge, J. M., Campbell, S. M., Hoffman, B. J., \& Lance, C. E. (2010). Generational differences in work values: Leisure and extrinsic values increasing, social and intrinsic values decreasing. Journal of management, 36(5), 1117-1142.

Urick, M. J., Hollensbe, E. C., Masterson, S. S., \& Lyons, S. T. (2017). Understanding and managing intergenerational conflict: An examination of influences and strategies. Work, Aging, and Retirement, 3(2), 166-185.

Van Rossem, A. H. D. (2018). Generations as social categories: An exploratory cognitive study of generational identity and generational stereotypes in a multigenerational workforce. Journal of Organizational Behavior, 40(4), 434-455.

Weber, M. (1978). Economy and society: An outline of interpretive sociology. Berkey, CA: Univ of California Press.

Weeks, K. P., \& Schaffert, C. (2019). Generational Differences in Definitions of Meaningful Work: A Mixed Methods Study. Journal of Business Ethics, 156(4), 1045-1061.

Weeks, K. P., Weeks, M., \& Long, N. (2017). Generational perceptions at work: in-group favoritism and out-group stereotypes. Equality, Diversity and Inclusion, 36(1), 33-53.
Westerman, J. W., \& Yamamura, J. H. (2007). Generational preferences for work environment fit: Effects on employee outcomes. Career Development International, 12(2), 150-161.

WVS Database. (2018). WVS Database (Online). Retrieved from http://www.worldvaluessurvey.org/WVSOnline.jsp

Yi, X., Ribbens, B., Fu, L., \& Cheng, W. (2015). Variation in career and workplace attitudes by generation, gender, and culture differences in career perceptions in the United States and China. Employee Relations, 37(1), 66-82.

Zaheer, A., McEvily. B., \& Perrone, V. (1998). Does Trust Matter? Exploring the Effects of Interorganizational and Interpersonal Trust on Performance. Organization Science, 9(2), 123-251.

Zak, P. J., \& Knack, S. (2001). Trust and growth. The economic journal, 111(470), 295-321.

Zanini, M. T. (2007). Trust within organizations of the new economy: A cross-industrial study. Karlsruhe, Germany: University of Verlag.

Zanini, M. T., Lusk, E. J., \& Wolff, B. (2009). Confiança dentro das organizações da nova economia: uma análise empírica sobre as consequências da incerteza institucional. Revista de Administração Contemporânea, 13(1), 72-91.

Zeffane, R. (2018). Do age, work experience and gender affect individuals' propensity to trust others? An exploratory study in the United Arab Emirates, International Journal of Sociology and Social Policy, 38(3/4), 210-223.

Zemke, R., Raines, C., \& Filipczak, B. (1999). Generations at work: Managing the clash of Veterans, Boomers, Xers, and Nexters in your workplace. New York, NY: Amacom.

Zucker, L. G. (1986). Production of trust: Institutional sources of economic structure, 1840-1920. Research in Organizational Behavior, $8,53-111$

Carmen Pires Migueles

ORCID: https://orcid.org/0000-0002-3003-3714

Senior Research Professor of Organizational Behavior/Corporate Culture in the Brazilian School of Public and Business Administration at Getulio Vargas Foundation (FGV EBAPE).E-mail: carmen.migueles@fgv.br

Marco Tulio Fundão Zanini

ORCID: https://orcid.org/0000-0002-2653-7151

Senior Research Professor of Organizational Behavior/SHR Management in the Brazilian School of Public and Business Administration at Getulio Vargas Foundation (FGV EBAPE). E-mail: marco.zanini@fgv.br

Juliana Carvalho

ORCID: https://orcid.org/0000-0001-8434-7594

Ph.D. student and research assistant in the Brazilian School of Public and Business Administration at Getulio Vargas Foundation (FGV EBAPE).

E-mail: juliana.carvalho.1@fgv.edu.br

Fernando Filardi

ORCID: https://orcid.org/0000-0002-9333-0871

Senior Research Professor of Strategy at Instituto Brasileiro de Mercado de Capitais. E-mail: fernando.filardi@ibmec.edu.br 